\title{
EDTA dependent red cell neutrophil rosetting in autoimmune haemolytic anaemia
}

\author{
J. E. PETTIT, J. SCOTT, AND SONAY HUSSEIN
}

From the Departments of Haematology and Medicine, Royal Free Hospital, London NW3 2QG

SYNOPSIS Disodium ethylenediaminetetraacetate (EDTA) dependent platelet-neutrophil rosetting is a well-known but infrequently reported in vitro blood abnormality. We describe a patient with autoimmune haemolytic anaemia in whom EDTA dependent red cell-neutrophil rosettes were a persistent blood film feature.

\section{Case Report}

A 28-year-old man was admitted with an exacerbation of chronic autoimmune haemolytic anaemia. In 1964 he had presented with a two-month history of malaise, anorexia, and jaundice. His spleen was not palpable at that time, and investigations had revealed a haemoglobin of $12.8 \mathrm{~g} / \mathrm{dl}$ and reticulocyte count $15 \%$; the direct antiglobulin (Coombs) test was positive and the serum unconjugated bilirubin was $82 \mu \mathrm{mol} / 1(4.8 \mathrm{mg} / 100 \mathrm{ml})$. Since this initial presentation he had remained reasonably well with a chronic anaemia with haemoglobin levels of between 8 and $11 \mathrm{~g} / \mathrm{dl}$. No underlying disorder had been found. During the first nine years of his illness acute exacerbations of his anaemia had been treated with prednisone, $10-15 \mathrm{mg}$ daily, but for the last two years he had received prednisone continuously.

On his most recent admission he was 'Cushingoid' and moderately jaundiced, and his spleen was just palpable. Investigations: haemoglobin $8.7 \mathrm{~g} / \mathrm{dl}$, reticulocytes $25 \%$, white cell count $6.8 \times 10^{9} / 1$ (neutrophils $3 \cdot 944$, eosinophils $0 \cdot 136$, lymphocytes $2 \cdot 584$, monocytes $0 \cdot 136$ ), platelets $210 \times 10^{9} / 1$; examination of the blood film revealed red cell polychromasia, anisocytosis and poikilocytosis, and red cell-neutrophil rosetting (figure), serum unconjugated bilirubin $44 \cdot 2 \mu \mathrm{mol} / 1(2.6 \mathrm{mg} / 100 \mathrm{ml})$. Serology: the direct antiglobulin (Coombs) test was positive due to complement on the red cell surfaces; the serum contained a weak nonspecific cold antibody which agglutinated cord and adult cells equally to a titre of 8 at $4^{\circ} \mathrm{C}$ and 1 at $20^{\circ} \mathrm{C}$ and which sensitized red cells to bind complement up to $30^{\circ} \mathrm{C}$.
The serum immunoglobins were within normal limits.

Red cell-neutrophil rosetting was consistently observed in routinely prepared blood films from EDTA anticoagulated blood during his last admission and other admissions in 1973 and 1974. Lymphocytes, monocytes, and other granulocytes failed to form rosettes. Over $75 \%$ of the neutrophils seen in the blood film were surrounded by between 5 and 40 red cells. Varying the temperature of the blood sample to between $15^{\circ} \mathrm{C}$ and $37^{\circ} \mathrm{C}$ did not influence the ability of the red cells to adhere to neutrophils. Red cell-neutrophil rosetting did not occur in films made from native blood or from blood anticoagulated with heparin or sodium citrate.

\section{Discussion}

In 1963, four letters to the editor of the British Medical Journal (Bolton and Boyd, 1963; Crome and Barkhan, 1963; Field and MacLeod, 1963; Signy and Green, 1963) described platelet adherence to neutrophils in five patients with various disorders. This adherence was also dependent upon the blood being anticoagulated in EDTA. In a later report describing this phenomenon (Kjeldsberg and Swanson, 1974) neutrophil phagocytosis of platelets was also observed. It has not been possible to relate this in vitro change to any particular clinical condition or laboratory finding or to drug therapy. The only clinical importance of EDTA dependent plateletneutrophil rosetting is that it may result in spuriously low platelet counts.

The mechanism of EDTA dependent red cellneutrophil rosetting in this patient is also unknown. The relative importance and role of complement components on the red cell surface, weak cold anti- 


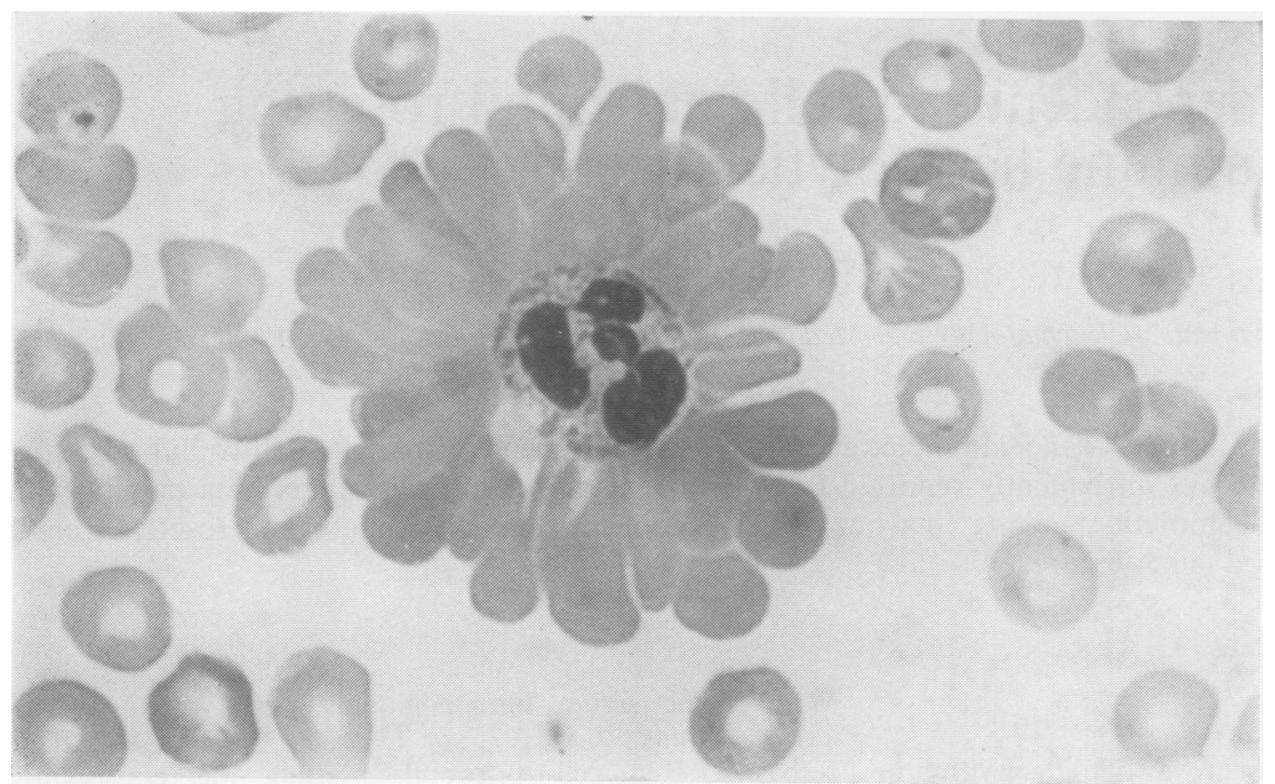

Figure Typical red cell-neutrophil rosette as seen in blood films made from EDTA anticoagulated blood.

body in the serum, EDTA and the neutrophil surface, remain to be defined. It seems unlikely that the chelating action of EDTA was important as citrate calcium-binding failed to produce rosetting. Mixing experiments with the patient's plasma and ABO-compatible blood failed to produce this phenomenon.

We thank Professor Sheila Sherlock for permission to study this patient and Dr Sheila Worlledge for the serological investigations.

\section{References}

Bolton, F. G. and Boyd, J. B. (1963). Platelet adherence polymorphs. (Letter.) Brit. med. J., $2,747$.

Crome, P. E. and Barkhan, P. (1963). Platelet adherence polymorphs. (Letter.) Brit. med. J., 2, 871.

Field, E. J. and MacLeod, I. (1963). Platelet adherence to polymorphs. (Letter.) Brit. med. J., 2, 388-389.

Kjeldsberg, C. R. and Swanson, J. (1974). Platelet satellitisno Blood, 43, 831-936.

Signy, A. G. and Green, A. E. (1963). Platelet adherence polymorphs. (Letter.) Brit. med. J., 2, 624. 